\title{
SCHOOL RANKINGS: THE US EXPERIENCE AND OPPORTUNITIES FOR UKRAINE
}

\author{
Liudmyla Sumbaieva ${ }^{1}$ \\ I «KROK»University, Kiev, Ukraine, ludmilasp@krok.edu.ua, ORCID: https://orcid.org/0000-0003-4514-8327
}

Citation:

Sumbaieva, L. (2020). School rankings: the us experience and opportunities for Ukraine. Economics, Finance and Management Review, (1), 86-92. https://doi.org/10.36690/2674-52082020-1-86-92

Received: January 08, 2020 Approved: March 22, 2020 Published: March 25, 2020

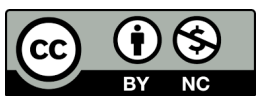

This article is an open access article distributed under the terms and conditions of the Creative Commons Attribution (CC BY-NC 4.0) license

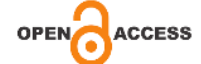

Abstract. Ukrainian education continues to take a way of reforms that covers all its levels, and on this way we are approaching the stage of improving the national ranking system of higher educational institutions and creating a ranking methodology for those types of educational institutions that are not currently covered by it. This is especially important today when the issues of financing the educational system are under recononsideration. This implies primarily to higher educational institutions, which must prove their need for existence in order to ensure the labor market, competitiveness and efficiency. As the global practice shows, ranking is a strong indicator of the future forecast for an educational institution as those institutions, that take a serious approach to it and the place they take in those ratings, do not consider consolidated lists merely as a PR tool, but systematically evaluate how they meet the modern requirements, analyze the factors that affect the rating, improve the level of academic quality and academic reputation, have all the opportunities for stable economic development, which gives them the opportunity to confidently look into the future.

In our view, research, analysis and, in the long term, the introduction of elements of world experience are important for improving the national rating system. The objective of our article is to study the rating experience in the United States based on the ranking system example of U.S. News and World Report "America's Best Colleges." This system has a time-tested methodology that is being constantly updated to respond to changes in the society, the needs of the economy and the labor market. The article analyzes and summarizes the main approaches of the methodology and the latest data released on October 15, 2019. The study is of practical importance, since the results of the systematization of the basic methodology principles of the U.S. news regarding rating of higher educational institutions rating may be effectively used in national practice.

Keywords: rating of educational institutions, ranking methods, categories of higher education institutions, stages of classification, academic reputation, academic quality.

JEL Classification: A20, A21, C43

Formulas: 0; fig.: 1; tabl.: 2; bibl.: 13

Introduction. Currently there are many educational institutions in Ukraine with a wide range of educational services, qualifications, specialties and specializations that coexist on the principles of healthy competition. Some of them are more prestigious, others are less, which is an important factor that affects the economic stability of their development. That is why educational institutions have to constantly work at moving up their place in national and world ranking lists, their level of accreditation, improving in technologies. One of the most effective tools in addressing these challenges is the use of criteria for assigning places in the ratings. It should be noted that the national rating systems require improvement and do not cover all levels of education. Therefore, it is important to study international experience and the principles set out in recognized world ranking systems, as their experience may perhaps be used in national practice. One such method is a method of editorial board of U.S. News and World Report that was one of the first in the world to create a ranking system of educational institutions and has an extensive experience in this field. 
Literature review. Formation of ratings of educational institutions is a subject of research that is of interest to scientists. Among those who studied the world methodology are as follows: Kurbatov S. (2008) "University rankings as an indicator of the state of education”, Ilnitsky D.O. and Sakharov V.E. (2011) "Methodological foundations for assessing international competitiveness of world-class research universities", Andreis Rauhvargers (2011) "Global university rankings and their impact", Gorpinich O.V. (2012) "Special features of the rating of higher educational institutions in Europe", Tatarinov I.E. and Gerasimov O.V. (2013) "World practice of university rating formation: defining the most objective criteria and evaluation indicators", Shostak A.V. (2017) "European Chamber rated universities" and others. Researchers pay great attention to improving the national rating system, using world-leading best practices: Gorpinich O.V. (2012) "Methodology of rating of higher educational institutions of Ukraine", Pavlova O.Yu. (2012) "Cultural integration of domestic higher educational institutions into the European educational environment", Prykhodko V.V. (2014) "Strategy of reform of the national higher education", Tsyuk O.A. (2016) "Special features of world and Ukrainian ratings of higher educational institutions" and other researchers.

Aims. The objective of our study is to systematize the main approaches of the methodology of the editorial board of U.S. News and World Report [2] to the school rankings and analysis of the changes therein that were introduced to create the 2020 rating as well as the reasons for the editing; identification of the main motivational reason for the creation of such ratings according to the said editorial board.

Methods. The methodological basis of the article is a method of logical generalization to find out the basics of the ranking methodology of the editorial board of U.S. News and World Report [2], an analytical method for analyzing and classifying innovations when making up the 2020 ranking. The information base of the study was the data posted on the web site of the U.S. News and World Report [2].

Results. Openness, transparency of higher education is now a challenge to the society, a reputation and a need. A step towards solving the problem of improving the quality of higher education is the implementation of external and internal monitoring of the quality of higher education and presentation of the monitoring results in the format of ratings of higher education institutions [9, c. 271-272].

Ranking and attempts to evaluate higher education institutions began in 1983 by the magazine named the U.S. News and World Report, which first published its ranking of America's Best Colleges [10, p. 123]. It stressed the undeniable importance of receiving a multi-level education in general, as it makes citizens economically protected. As evidence of the relevance of such a rationale today, the latest research materials contain data from the Bureau of Labor Statistics of the United States (Figure 1) [1]. 
UNEMPLOYMENT RATE (\%)

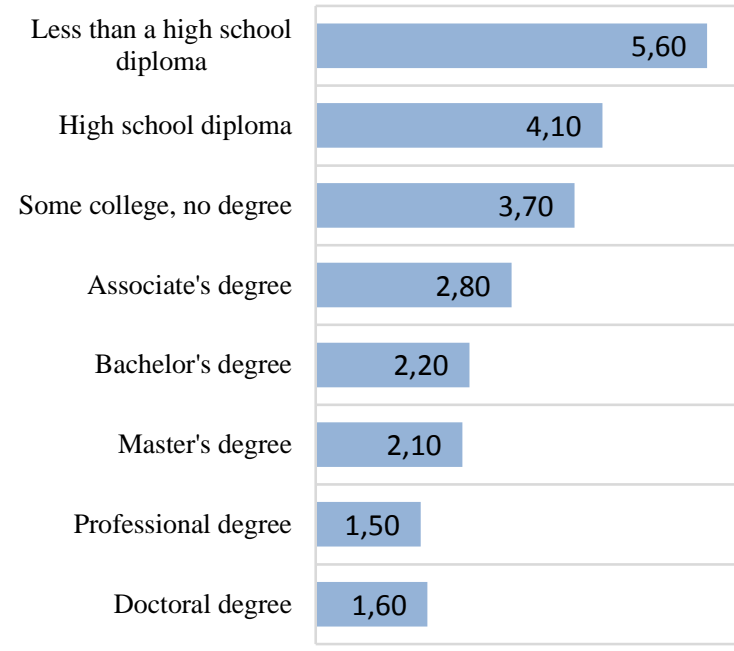

MEDIAN USUAL WEEKLY EARNINGS (\$)

553,00

730,00

802,00

862,00

1198,00

1434,00

1884,00

1825,00

\section{Figure 1. Unemployment rates and earnings by educational attainment,} 2018

Note: Data are for persons age 25 and over. Earnings are for full-time wage and salary workers Source: Current Population Survey, U.S. Department of Labor, U.S. Bureau of Labor Statistics

The need to start a description of the activities of the educational institutions in the form of rating was explained by the importance of making a reasonable choice by the applicants of a qualitative place for education, so that the funds invested in education bring decent pay and stable professional success in the future.

The rating of American higher educational institutions was based on the criteria as follows: evaluations by representatives of the administration of other universities; the ratio of the number of graduates to the number of first-year students; the results of standardized admission tests; the proportion between the number of documents submitted for admission and the number of students enrolled; quality of teaching and academis staff and teachers' salaries; financial costs for the preparation of one student; evaluation of the quality of education by graduates [8, c.312-313].

The latest data discussed in this article were collected in the spring of 2019 for the Best Colleges 2020 edition and published on October 15, 2019.

US News starts ranking by placing educational institutions by categories according to the mission they perform, and in some cases, even according to their location. The ranking is carried out within a group of one-level educational institutions based on the same set of quality indicators.

Discussion. The purpose of creating such groups is an ambition to carry out an objective comparison of educational institutions with similar missions. As an example, the editorial board cites the institutions that focus on research activities and those that focus solely on student teaching. Such educational establishments differ from each other and have different structures. The rating categories for Best Colleges 2020 were created by the editorial board of US News in accordance with the updated Carnegie Higher Education Classification Database 2018. US News has formed the following categories, namely national 
universities, national colleges of liberal arts, regional universities, regional colleges. National universities are ranked separately from National Colleges because they offer several doctoral programs, and regional colleges are in a different group and are included in different subgroups depending on the region of location.

After the classification stage, the collection of information begins according to indicators, each of which has its own weight, which is expressed as percentage.

The ratios of the main indicators based on which the ranking of higher educational institutions is made are presented in Table 1.

Table 1. The ratios of the main indicators based on which the ranking of higher educational institutions is made

\begin{tabular}{|l|l|}
\hline \multicolumn{1}{|c|}{$80 \%$} & \multicolumn{1}{|c|}{$20 \%$} \\
\hline $\begin{array}{l}\text { Formula in which such statistical indicators of } \\
\text { quality of education are used including level of } \\
\text { graduates, social mobility, information about } \\
\text { teachers, data on enrollment, etc. }\end{array}$ & $\begin{array}{l}\text { Academic reputation as determined by external } \\
\text { expert peer review provided by representatives } \\
\text { of educational institutions belonging to the same } \\
\text { group }\end{array}$ \\
\hline
\end{tabular}
Source: developed by author

At the same time, the management of educational institutions is required to ensure maximum accuracy of the presented indicators and reconciliation of potential problems with the answers, which are marked by the US News data system. Then analysis of the ratings by indicators compared to previous data, data from other educational institutions and external sources is made. During the summarization process specialists repeatedly contact the management of the institutions for further clarification on the information provided.

When determining a rating of the academic reputation through the formation of an external peer review, the magazine's editorial board gets in touch with the presidents, pro-rectors, heads of admissions committees with a request to evaluate the quality of the academic programs of their own educational institution and the institutions of the group, their educational institution belongs to. If the institution is unfamiliar to them, a special mark is put.

The third step is to create a rating based on the total score. US News publishes the results, and a rating scale is built according to the rating, consisting of $3 / 4$ of participants of the ranking process. Other educational institutions that failed to get shortlisted are arranged alphabetically. It should be noted that only accredited educational institutions, which prepare bachelors based on four-year programs and have at least 200 students are evaluated. Thus, 213 out of 1,600 educational institutions were not ranked in the last rating campaign.

The magazine's editorial board is constantly updating information about American school rankings, refining the methodology and making their best to ensure that it is as objective and fair as possible. Discussions are constantly underway on how to best measure the quality of education. To achieve this goal, 
advisory groups are created, the magazine's analysts attend conferences, research the literature on special features of the modern education, and they do not miss opportunities to take into account the comments and wishes of users and study the contemporary trends. If new visions or suggestions emerge in the process, they are thoroughly researched and accepted as they improve the quality of the rating.

Thus, due to the increased attention of researchers, educators, employers to performance-related indicators, far less attention to quality indicators that take into account the characteristics of students, teachers and other resources is paid to in the ranking model [2].

The methodology for calculating the 2020 rating has also been modified. Table 2 shows the most significant changes in the ranking methodology of higher educational institutions in 2020.

Table 2. Changes in the ranking methodology of higher educational institutions in 2020

\begin{tabular}{|c|c|}
\hline Changes & Justification of changes \\
\hline $\begin{array}{l}\text { The management of the educational institution } \\
\text { must confirm the accuracy of the statistic data } \\
\text { provided }\end{array}$ & $\begin{array}{l}\text { The requirement should encourage a more } \\
\text { thorough review of the data before submission }\end{array}$ \\
\hline $\begin{array}{l}\text { The list of institutions that can participate in the } \\
\text { rating has changed }\end{array}$ & $\begin{array}{l}\text { The need to meet the updated Carnegie } \\
\text { Classifiers called "The } 2018 \text { Update" }\end{array}$ \\
\hline $\begin{array}{l}\text { Evaluation of curators of senior students from } \\
\text { the rating formula of National Universities and } \\
\text { National Colleges of liberal arts has been } \\
\text { excluded }\end{array}$ & $\begin{array}{l}\text { Such an evaluation has never been a rating } \\
\text { indicator in the methodology of calculations for } \\
\text { regional universities and regional colleges. }\end{array}$ \\
\hline $\begin{array}{l}\text { The percentage of first-year students has been } \\
\text { added to the calculations of success rates }\end{array}$ & $\begin{array}{l}\text { This gives schools more recognition for } \\
\text { graduation-year students vs to the percentage of } \\
\text { those admitted to colleges }\end{array}$ \\
\hline $\begin{array}{l}\text { Two indicators of social mobility are calculated } \\
\text { using the two-year average of autumn } 2011 \text { and } \\
\text { autumn } 2012\end{array}$ & $\begin{array}{l}\text { A two-year average value over two periods was } \\
\text { used to reduce the statistical error }\end{array}$ \\
\hline New indicators of teachers' salaries & $\begin{array}{l}\text { It has been adjusted using the data of open } \\
\text { resources of the Bureau of Economic Analysis } \\
\text { for } 2017 \text { published in May } 2019\end{array}$ \\
\hline $\begin{array}{l}\text { Increased use of external data to rank such } \\
\text { factors as financial resources, social mobility } \\
\text { and teachers' salaries }\end{array}$ & $\begin{array}{l}\text { The schools did not provide data directly to US } \\
\text { News }\end{array}$ \\
\hline $\begin{array}{l}\text { In addition to the overall rating, for the first } \\
\text { time since } 2003 \text { US News has created a } \\
\text { separate rating that evaluates educational } \\
\text { institutions in the areas such as first-year } \\
\text { experience, internships, educational } \\
\text { associations, higher education, service for the } \\
\text { educational process, studies abroad, research } \\
\text { / creative projects of students, written works } \\
\text { in disciplines }\end{array}$ & $\begin{array}{l}\text { It has been proven that the said parameters } \\
\text { enhance the learning outcomes and academic } \\
\text { experience of students }\end{array}$ \\
\hline
\end{tabular}

Source: developed by author 
Since 1990 US News has been working with some American schools that have no ratings because it finds it incorrect to include them in comparative statistics. These are specialized institutions, most of which offer specialties such as fine arts, vocal art, business and others. In 2019 they totaled 322 educational institutions out of 1,922 polled and grouped into specific categories.

The rating of the best educational institutions evaluates the academic quality, and the non-academic indicators are not taken into account. The statistic indicators US News takes into consideration include the following: social mobility, a ratio of students enrolled to those finished the first year of studies, expert opinion, faculty resources, students' success, financial resources, alumni evaluation, success rate determined by comparing the number of alumni expected and alumni actual.

Conclusions. Rankings of higher educational institutions are required for applicants to choose a higher educational establishment, for the administration of higher educational institution - for effective administration, for employers for selecting an adequate workforce, for government and politicians - for forming a stable legal framework and ensuring the adequacy of the educational services and labour market. Therefore, the rating system should satisfy all consumers of educational services and organizers of higher education [12, p. 58]. In our opinion, this is the right way to create the national ratings of educational institutions, produce and improve existing ranking methods. The world rankings in this matter are a good foundation, as they have a long history and invaluable time-tested experience. The methodology of editorial board of US News is particularly noteworthy.

\section{References:}

1. United States Department of Labor Unemployment rates and earnings by educational attainmen (2020), retrieved from : https://www.bls.gov/emp/tables/unemployment-earnings-education.htm.

2. Frequently Asked Questions: 2020 Best Colleges Rankings вy Robert Morse, Eric Brooks, and Matt Mason (2020), retrieved from : https://www.usnews.com/education/bestcolleges/articles/rankings-faq.

3. Andrejs Rauhvargers Global University Rankings and Their Impact (2020), retrieved from : https://eua.eu/resources/publications/384:global-university-rankings-and-their-impact.html.

4. Baty, Phil (2020), "THE unveils broad, rigorous new rankings methodology. Times Higher Education", retrieved from : https://www.timeshighereducation.com/news/the-unveils-broad-rigorousnew-rankings-methodology/411907. article?sectioncode $=26 \&$ storycode $=411907 \& \mathrm{c}=1$.

5. Horpynych, O. V. Salov, V. O. and Yamkovyi, V.A. (2012), "Methodology of rating higher education institutions of Ukraine", Upravlinnia yakistiu pidhotovky kadriv z vyshchoiu osvitoiu cherez udoskonalennia protsedur litsenzuvannia, akredytatsii ta reitynhuvannia [Quality management training for higher education through improving licensing, accreditation and rating procedures], Naukovo-metodychna konferentsiia [Scientific and methodological conference], National Mining University, Dnipro, Ukraine, pp. 126-129, retrieved from : http://ir.nmu.org.ua/handle/123456789/3408?show=full.

6. Horpynych, O. V. (2012), "Rating features of higher education institutions in Europe", Upravlinnia yakistiu pidhotovky kadriv z vyshchoiu osvitoiu cherez udoskonalennia protsedur litsenzuvannia, akredytatsii ta reitynhuvannia [Quality management training for higher education through improving licensing, accreditation and rating procedures], Naukovo-metodychna konferentsiia [Scientific and methodological conference], National Mining University, Dnipro, Ukraine, pp. 122-126, retrieved from : http://ir.nmu.org.ua/bitstream/handle/123456789/3407/122-126.pdf?sequence=1\&isAllowed=y. 
7. Ilnytskyi, D. O. and Sakharov, V. Ie. (2011), "Methodological principles of international competitiveness assessment of world-class research universities", Aktualni problemy ekonomiky, №11, pp. 152-168.

8. Kurbatov, S. (2008), "University ratings as an indicator of the state of education", Filosofiia osvity, № 1-2(7), pp. 309-317.

9. Pavlova, O. Yu. (2012), Kulturna intehratsiia vitchyznianykh zakladiv vyshchoi osvity do Yevropeiskoho osvitnoho seredovyshcha [Cultural integration of national higher education institutions into the European educational environment], KIM, Kyiv, Ukraine, 298 p.

10.Prykhodko, V. V. (2014), Stratehiia reformy natsionalnoi vyshchoi shkoly [National higher education reform strategy], Zhurfond, Dnipropetrovsk, Ukraine, $460 \mathrm{p}$.

11.Tatarinov, I. Ye. and Herasymov, O. V. (2013), "World universities ranking practice: defining the most objective criteria and rating indicators", Ukrainskyi sotsium, № 1(44), pp. 100-116, retrieved from $\quad: \quad$ https://ukr-socium.org.ua/wp-content/uploads/2013/01/100-116_no-1_vol44_2013_UKR.pdf.

12.Tsiuk, O. A. (2016), "Features of world and Ukrainian ratings of higher education institutions", Ukrainskyi pedahohichnyi zhurnal, № 2, pp. 57-62, retrieved from : http://uej.undip.org.ua/upload/iblock/2ef/2ef439f56e122ea4edd7cb6696c8598d.pdf.

13.Shostak, A. V. (2017), "The European parliament has rated universities", World science, International Scientific and Practical Conference, Vol.3. № 6(22), pp. 4-15, retrieved from : https://www.academia.edu/37979068/. 